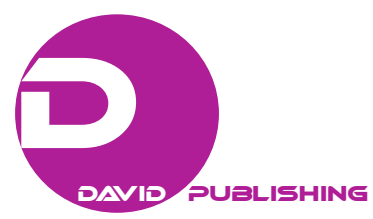

\title{
Should the Companies Invest in Innovation?
}

\author{
Andreas Votteler, Monika Zatrochová \\ Comenius University, Bratislava, Slovakia
}

\begin{abstract}
In the beginning, this template describes the actual situation on the market. As a second point, there is a description and a classification of the different kinds of innovation. The object of this template is a scientific examination of the interrelation between innovation and the companies' future development. Today's markets are changing rapidly. The environment alters faster and faster. Business companies are forced to adapt to these changing conditions. They have to develop new and adjusted products to be successful on these markets. Companies are offering their products on markets. The more customers' requirements those products fulfil, the more likely they will be bought. Innovation can be described as a process of transforming a concept into a product, good, or service. Real innovation is seldom, though. More often, innovation is a result of a known solution being transferred into a new context. There are different forms of innovation. In general innovation can be classified in: basic innovation, product improving innovation, product adjusting innovation, imitation and pretended innovation. These different kinds of innovation can occur within a company as a process, or in a market as a newly developed product. The future of a company depends in many ways on the newly developed products, which in turn are depending on the needs of the customers. Those needs are not always known and needs could also be generated by inventing new technologies. Companies have to consider the development of new products and manufacturing processes in order to stay successful.
\end{abstract}

Keywords: innovation, kind of innovation, market, marketing, marketing strategy, strategy

\section{Design and Structure of the Paper}

Companies have to keep costs as low as possible. It might be tempting to disclaim investments in innovation, which is first of all an expense factor. This contemporary issue will be researched in this thesis.

Some of the basics used in this paper have already been discussed by the author in the book Methoden der Ideenfindung in der Produktentwicklung. Innovationen als Zukunftschance für Unternehmen. The ideas of that book will be further developed in this paper.

The central issue of this paper is to be determined by an academic research, if investments in innovation are worthwhile for companies.

At the beginning the technical terms are defined and described, starting with an explanation of the term market.

The market is a meeting point of different powers, such as seller and buyer. It is also the fundament of every decision made by a company. What are the main issues to make a company successful?

Andreas Votteler, MBA, Ph.D. student, Comenius University in Bratislava (Management), Bratislava, Slovakia.

Monika Zatrochová, Ph.D., professor of Comenius University in Bratislava, Slovakia.

Correspondence concerning this paper should be addressed to Andreas Votteler, Teufenstr. 17, 78667 Villingendorf, Germany. 
Marketing is a tool for the companies to be able to keep up with the market requirements through their own development. Marketing offers an overview about what the customers want now and in the future.

Considering the information given by marketing, companies have to create an own strategy concept. To accomplish the survival of a company, the actual market position has to be maintained. To accomplish a growth of the company, the competitors have to be outmatched to gain bigger market shares.

The next subject will be the term "innovation". What is innovation and what is the use of innovation?

The description of innovation will be followed by a sub-classification of innovation into the different kinds of innovation and their description.

Finally there is a summary of the previous chapters, resulting in an answer to the original question "Should the companies invest in innovation?"

\section{Research Methods}

This thesis consists of theoretical research and conclusions, based on literature research and theoretical paradigms. To answer the question "Should companies invest in innovation?" the issue is split up into three basic aspects.

The first part is an examination of a company's position and environment such as the market.

The second point is a close inspection of marketing as a link between the company with their products and the market with its customers (actual and possible).

The last point is the definition of innovation.

The result of these three parts is the solution to the question if companies are to invest in innovation.

\section{Market}

The market can be sub-classified into different product and service segments. But there are some problems with the breaking down to sub-segments (Freter, 2008, p. 37).

Also is the market the meeting point between buyer and seller for goods. In this definition, goods include as well services. The market is the meeting place between the seller and the customers but also the competitors. The whole market can be broken down to some segments to reduce the complexity and get a better overview. Today's markets are changing rapidly. The environment alters faster and faster. Business companies are forced to adapt to these changing conditions. They have to develop new and adjusted products to be successful on these markets.

\section{Surviving on the Market}

The products manufactured by a company are sold on the market. Selling products (or services) is the core mission of each company. The better the products, or rather the solution for the customer's problems is, the more products can be sold.

From a customer's point of view, products have to solve his problems for an acceptable price. For a seller, a competitor is another seller, who also offers a solution for the same customer's problem. The decision about who is a competitor is made by the customer, depending on his requirements.

To survive on the market, it is also important to get information about the competitor.

Observing the actions and strategies of the rivals is also a way to gain information about the customer's orientation (Hooley, Piercy, \& Nicoulaud, 2008, p. 121). If the competitor has new technologies, develops a new product feature or something more, the other companies have to provide at least equal conditions or lower the price in order to maintain their market shares. 
Competition and the customers' requirements push the need of innovation forward.

To expand their market shares, companies are to bring some product or marketing innovation, like better products or a better strategy to advertise their products. Both possibilities start with thinking about a new solution, or a different kind of use. This can be named as innovation, or the start of an innovation process.

Companies make money by selling their products on the market. The customer would buy the products which provide the best solutions for the customer's demands. Researching the customer's expectations and wishes is necessary to accomplish this task.

Not only the actual, but also the future needs of the customers have to be investigated.

The basic approach of marketing is the analysis of the demands which will be satisfied by the product now and in the future. Who are the competitors, who the customers, on which markets can the products be placed?

Purpose of the analysis is getting information about which expectations the product should meet and how the product could be set apart from the competitive products (Kasprik, 2002, p. 105).

\section{Marketing}

The main issue of marketing is the customer and market orientation of the company. Every activity of the company should be oriented on the customers' needs. Customer orientation is also the guiding principle of marketing.

Therefore all the managerial decisions should be in line with the actual and future expectable needs, wishes and problems of actual and future customers (Froboese \& Andreas, 2010, p. 22).

Marketing is a corporate thinking attitude, which will be substantiated by the analysis, planning, implementation, and control of all internal and external company activities. The company has to appreciate the customer and demonstrate this appreciation to bind him as a regular customer (Bruhn, 2010, p. 14).

The seller communicates with the buyer via marketing activity and via products. The products are the most important aspects of this communication. Marketing is used as a backup strategy to the products. A good marketing and marketing strategy can't replace a good product. The objective of the seller is also knowledge about the customer needs. But price and service may not be forgotten.

Marketing is interdisciplinary in two directions. First there are different academic categories: sociology, psychology, engineering, law, managerial-economics as well as natural sciences. On the other hand there are different options in the usage: market research, purchase, HR, product and price design as well as strategic orientation. Also marketing is a way to monitor the customers and environment but also a communication tool. Furthermore, marketing is used for the implementation and adaptation to the market requirements.

All internal activities of a company should follow the structure, which will be organised by marketing. The strategy will be developed in consideration of the market needs. The type of company should be considered.

Table 1 provides an overview over some marketing strategies. All of the strategies include a certain risk. But there is no possibility to generate profit without risk. The strategy is future oriented, but nobody can foretell the future.

For the creation of a strategy it is important to know what the customers expect and what they are ready to pay for the product. The second important aspect for the company is the costs. The producing costs should be much lower than the amount customers who would pay for the product. The company should regain all the invested money and all the costs, as well as a surplus to outweigh the risk and for the investment in new products. 
Table 1

Marketing Strategies (Votteler, 2015, p. 67)

\begin{tabular}{|c|c|c|c|c|}
\hline Strategies & Characteristic & & & \\
\hline Experience curve & Experience high & Experience low & & \\
\hline BCG portfolio matrix & Question marks & Stars & Cash cows & Poor dogs \\
\hline Mckinsey & Investment & Selection & Disinvestment & \\
\hline $\begin{array}{l}\text { Division-resource portfolio } \\
\text { to Albach }\end{array}$ & Substitution possibilities & Critical resource & & \\
\hline PMS & Relative market share & Relative quality & ROI & \\
\hline Matrix of influence & Strong influence & Weak influence & & \\
\hline SWOT analysis & Strengths & Weakness & Opportunities & Threats \\
\hline U corve to Porter & Specialist (differentation) & Stuck in the middle & $\begin{array}{l}\text { Generalist (lower } \\
\text { cost) }\end{array}$ & \\
\hline Market entry strategy & Pionier (product new) & Early follower, variation & Late follower, me-too & \\
\hline Product market matrix to Ansoff & Market penetration & Market development & Product development & Diversifikation \\
\hline Product life cycle & Launch & Grow & Maturity & Degeneration \\
\hline
\end{tabular}

Companies have to adapt their linecard to the changing market requirements. Obsolete products can't be sold to the customers - at best for a very small price. An innovative company is able to influence the market. But every investment has to be paid.

The result of every innovation is a new product. The quality of an idea or a product alone can't guarantee a good result on market.

If the innovation displeases the usage of the customer or is too complicated for the customers, only a few people will claim the offer (Kamiske, 2010, p. 11). These customers are the "lead users". If the idea is new and very different, it takes some time until a trend can develop. This developing process costs a lot of money and a lot of marketing activities. But if the product gets more popular, the company benefits and has a lead position. The company can make use of some protection of the innovation like patent, petty patent and some more to keep the lead against possible imitators.

\section{Innovation}

Innovation includes both major and minor changes. An extremely major change is called a radical innovation and a cumulate series of minor changes is called an incremental innovation (Urabe, Child, \& Kagono, 1988, p. 3).

Completely new ideas are really seldom, like the LED or touchscreen. Innovation means to do things or processes in a new way. Generally, innovation consists of old ideas, which are implemented as a new combination or a new process. The innovations arise on the end of a long creative development process. This process starts with creative thinking ideas. Creativity technics allow the connection of different knowledge in different correlation or the transformation of existing ideas to a new context.

Often new ideas are discovered accidentally, while the researcher is looking for a solution for a complete other problem.

Innovation requires not only financial investments, but also a certain amount of time which should be scheduled.

\section{Innovation}

Sundbo's (2003, p. 19) definition of the innovation is: The Innovation will...mean the work of developing 
an invented element for practical and commercial use and of ensuring that the introduction of the element is accepted.

Innovation consists of the generation of a new idea and its implementation into a new product (and service), process or as a new management. Innovation is never a one-time phenomenon, but a long and lasting process beginning with the generation of a new idea to its implementation phase. New ideas are coming up with the detection of a new customer need or a new way to produce (Urabe et al., 1988, p. 3).

Product innovation should create new products, with a unique proposition. It is easier to sell unique products, than a copy of another product. The second case is known as the me-too strategy, the innovation process should be concentrated on process reformation and innovation to reduce the costs and change minor details of the products.

Generally, innovation begins with researching, which is not always orientated towards profit. Research can be done by universities, schools, companies, etc.

Based on the results of the research, the companies calculate the possible success of the new ideas on the market. These ideas will be developed further by the companies into new products. The time before the new products can be brought to the market is very critical. If the company doesn't have enough resources, other companies could take advantage of this and develop their own me-too products, gaining the benefits of being first on the market.

Schumpeter describes the innovation process as a creative destruction process, as a perennial gale of creative destruction. In this case Schumpeter classifies the short- and long-term innovation. Long-term innovation is the more effective option. To be able to invest into long-term innovation, protection against imitation is necessary. This is possible for example with patents and secret process (Schumpeter, 2012, p. xxxvii).

Without protection, companies would not invest in innovation. There has to be as much protection as is needed to guarantee that the financial resources invested can be regained before there are imitators with similar products on the market.

After this time the protection should be stopped. Otherwise there will be a monopoly position and that also restrains the innovation process.

If companies don't invest in innovation, the old products will soon be replaced by new fabrications, with the result of shrinking market shares and profit. This phenomenon is called "creative destruction". This practice is economical unviable in the long term. As a consequence, investing in innovation is obligatory for a company to survive.

The investment should be adapted to the marketing strategy and the question if long- or short-time investment will be taken.

There are different ways to describe the term "innovation". The differences can be divided in sections such as market innovation or company innovation, innovation of usage, and improving innovation.

Innovation of usage implies the creation of a new need, which did not exist in that way before. This kind of innovation is most often initiated by the technological change. New products replace the old ones and push them away from the market. An example would be the DVD player, which replaced the video player.

Innovation of usage means a new way of usage of an already existing solution. These solutions can also be transferred from another sector. 
Improving innovation can either apply to the process or the product itself. This kind of innovation takes place in the enterprise level.

\section{Kinds of Innovation}

Corresponding to the grade of novelty and innovation can be differentiated between abrupt (radical) and gradual (incremental) innovation (Gaubinger, Werani, \& Rabl, 2009, p. 6).

Innovation can be sub-classified according to the level of novelty into the following stages (Gaubinger et al., 2009, p. 7):

- Basic innovation

Basic innovation is the highest level of innovation. Such innovations are characterized by completely new active principles, technologies, or processes. These are innovations in the classical meaning. They are the foundation for numerous smaller innovations. This would be for example the development of the wheel, the steam-engine, the combustion motor, or the microprocessor.

- Improving innovation

Improving innovation is a lower innovation level than the basic innovation. Improving innovation tends to be the refinement of basic innovations. The main functions are preserved, while single function is further developed, adapted, or changed.

- Adapting innovation

Adapting innovation is a middle or low level of innovation. The product features are adapted to the customers' wishes. The results are different variations of the primary product.

- Imitation

Imitations are copies of already existing products produced by another company, resulting in similar or identical products. The level of innovation is low.

- Pretending innovation

Pretending innovation is modifications without a real value or benefit. The level of innovation is also very low.

The following chart demonstrates the differences of several kinds of innovation.

Table 2

Differences of Several Kinds of Innovation (Votteler, 2015, p. 3)

\begin{tabular}{llllll}
\hline Kind of innovation & Market innovation & $\begin{array}{l}\text { Company } \\
\text { innovation }\end{array}$ & $\begin{array}{l}\text { Degree of } \\
\text { innovation }\end{array}$ & Costs of innovation & Market \\
\hline Basic innovation & yes & yes & very high & very high & new \\
Improving innovation & yes & yes & high & high to middle & new, old \\
Adapting innovation & conditional & yes & low to middle & middle & old + niche \\
Imitation & no & yes & low & low & old \\
Pretended innovation & no & no & low to minimal & very low & old \\
\hline
\end{tabular}

Sundbo (2003, p. 21) defines the different types of innovation:

- A new product or new service,

- A new production process,

- A new organizational or management structure,

- A new type of marketing or overall behaviour on the market.

The innovation can also have different characters (Sundbo, 2003, p. 21): 
- Technological (objects),

- Intellectual, e.g. consultancy,

- Physical movements (which are not technology), e.g. a new transport (but without a change in technology),

- Behavioural, e.g. a new strategy for the company’s market behaviour or a new organizational structure.

\section{Research Results: Should the Companies Invest in Innovation?}

Today's research and development are tomorrow's products and services.

Innovations are of vital importance for the companies. Only innovations enable the opportunity to survive on the market permanently, they are the key to lasting success and securing the company's future (Herrmann \& Huber, 2009, p. 122).

Companies are under the pressure to succeed and so they aim to grow and move forward. It is not sufficient to keep the actual level, it's necessary to keep ahead of the competitors. An exception to this rule is the monopolists. Monopolists don't need to invest in innovation because they have a secure position and investments would only lower the profit.

All other companies have to fight with the competitors for market shares. If they don't invest in innovation, they will lose market share and such a company won't last very long.

But the investment should be suitable to the company's strategy. For example if the company has a leading market position as an innovation company, investments should be placed in product developing, if the company has a position as a cost leader, they should invest in the process to lower the costs and optimise the product to their own requirements.

Innovations destroy old solutions and replace them. Given the same price, the customer prefers the new solution. If a competitor offers a new solution, the company is expected to build at least an as good or better solution.

In order to grow and conquer new markets, the company has to develop new products which have to be accepted on the market or offered on a new market. Chances and risks of offering new products on new markets are very high as the circumstances are incalculable.

\section{Conclusion}

Companies will only invest in innovation, if there is a benefit in form of growth or profit.

The national economy's capability and competitiveness are depending in an essential way on the investments done by the companies and the government. At the same time investments can be conductive to the increase of the efficiency of resources and energy, as through power-saving renovations, the realization of ecological efficient methods of engineering or the production of eco-friendly goods (Bundesamt, 2014, p. 122).

Development and research determine the future and are of great economic importance, guaranteeing long-term wealth.

Innovation is always an expense factor. Cutting down expenses for innovation gives a company a short-time advantage. But in the long run, today's products will be replaced by new ones. A company that doesn't invest in innovation can’t provide marketable products. Outdated products can only be sold for a cheap, unprofitable price. So innovation is obligatory for the survival of the company. 


\section{References}

Bruhn, M. (2010). Marketing (p. 14). Wiesbaden: Gabler Verlag.

Bundesamt, S. (2014). Nachhaltige Eintwicklung in Deutschland, Indikatorenberich (p. 122). Wiesbaden: Statistisches Bundesamt.

Freter, H. (2008). Markt- und Kundensegmentierung (p. 37). Stuttgart: W. Kohlhammer GmbH.

Froboese, M., \& Andreas, K. (2010). Marketing (p. 22). Stuttgart: Steinbeis-Hochschule Berlin.

Gaubinger, K., Werani, T., \& Rabl, M. (2009). Praxisorientiertes Innovations- und Produktmanagement (pp. 6-7). Wiesbaden: Gabler/GWV Fachverlage GmbH.

Herrmann, A., \& Huber, F. (2009). Produktmanagement (p. 122). Wiesbaden: Gabler/GWV Fachverlage GmbH.

Hooley, G., Piercy, N. F., \& Nicoulaud, B. (2008). Marketing strategy and competitive positioning (p. 121). Gosport: Ashford Colour Press Ltd.

Kamiske, G. F. (2010). TRIZ-Innovation mit system (p. 11). München: Carl Hanser Verlag.

Kasprik, R. (2002). Rationale unternehmens- und Marketingplanung (p. 105). Heidelberg: Physica-Verlag.

Schumpeter, J. A. (2012). The theorie of economic development (p. xxxvii). USA, New Brunswick and UK, London: Transaaction Publishers.

Sundbo, J. (2003). The theory of innovation (pp. 19, 21). UK, Cheltenham and USA, Northampton: Edward Elgar Publishing.

Urabe, K., Child, J., \& Kagono, T. (1988). Innovation and management: International comparison (pp. 3, 11). Berlin and New York: Walter de Gruyter.

Votteler, A. (2015). Methoden der Ideenfindung in der Produktentwicklung (pp. 3, 67). Germany, Saarbrücken: Akademikerverlag. 